\title{
Peptide platforms for metal ion sensing
}

Barbara Imperiali, Dierdre A. Pearce, Jean-Ernest Sohna Sohna, Grant Walkup, Alicia Torrado

Barbara Imperiali, Dierdre A. Pearce, Jean-Ernest Sohna Sohna, Grant Walkup, Alicia Torrado, "Peptide platforms for metal ion sensing," Proc. SPIE 3858, Advanced Materials and Optical Systems for Chemical and Biological Detection, (15 December 1999); doi: 10.1117/12.372909 


\title{
Peptide Platforms for Metal Ion Sensing
}

\author{
Barbara Imperiali, $a, b^{*}$ Dierdre A. Pearce, ${ }^{a, b}$ Jean-Ernest Sohna Sohna, ${ }^{a}$ \\ Grant Walkup, ${ }^{a}$ and Alicia Torrado $a$

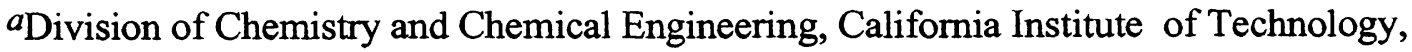 \\ 1200E. California Blvd, Pasadena CA, USA \\ ${ }^{b}$ Now at Department of Chemistry, Massachusetts Institute of Technology, \\ 77 Massachusetts Ave, Cambridge MA, USA
}

\begin{abstract}
ABS TRACT
Naturally occurring motifs have been redesigned to produce fluorescent peptidyl-chemosensors that sensitively and selectively recognize $\mathrm{Cu}$ (II) or $\mathrm{Fe}$ (III). The modular nature of peptide architecture allows preparation and evaluation of potential sensors on solid supports.
\end{abstract}

Keywords: Fluorescence, Metal Ion Recognition, Peptide, Chemosensor.

\section{INTRO DUCTION}

Nature provides many examples of peptidyl-motifs and small molecular weight species that form stable, selective complexes with many transition ions. ${ }^{1}$ This paper describes how some of these naturally occurring motifs have been incorporated into fluorescent chemosensors for detection of certain transition metal ions under biological and near biological conditions. Such sensors are of intense interest as more is known of the influence concerning species such as $\mathrm{Cu}$ (II), $\mathrm{Zn}$ (II) and $\mathrm{Fe}$ (III) on cellular processes, 2,3 disease states, 4,5 and the biosphere. ${ }^{6}$

The methodology used in the design of these chemosensors includes identification of an appropriate metal ion binding motif and modification of that motif to simplify it, or reduce the size by inccluding only the units necessary for coordination to the metal ion of interest. Modifications may include incorporation of non-natural amino acids or changes to the secondary structure of the motif and are achieved by solid phase peptide synthesis methods. Finally, a fluorophore is incorporated into the molecule to report the metal binding event.

Ideally, the end products of this design process are robust, low molecular weight species that detect, in real time, the low concentrations of species such as $\mathrm{Cu}$ (II) and $\mathrm{Fe}$ (III) in the presence of significantly higher concentrations of competing species such as $\mathrm{Ca}$ (II) and $\mathrm{Mg}(\mathrm{II})$ that are typical in biological and environmental samples.

Fluorescence signaling of metal ions has the significant advantages of great sensitivity, ${ }^{7}$ ready incorporation of chemosensors into optical monitoring devices ${ }^{8}$ and nondestructive detection of intracellular ion flux. ${ }^{9}$ As the sensors described in this paper have been designed to bind selectively to $\mathrm{Cu}$ (II) or $\mathrm{Fe}$ (III), metal ion recognition by the peptide is signaled by the intramolecular quenching fluorescence emission from a fluorophore covalently bound to the peptide sequence as illustrated schematically in Figure 1.

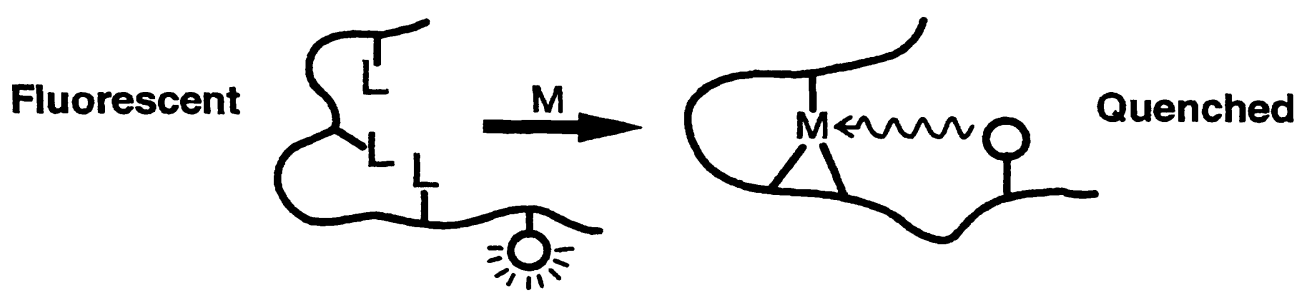

Figure 1. Metal binding by the peptide causes quenching of emission from the pendent fluorophore.

* Further author information send correspondence to BI (E-mail: imper@mit.edu) 


\section{DESIGN OF SELEC TIVE CHEMO SENSORS FOR CU(I)}

An example of our design approach is the development of chemosensors for selective detection of $\mathrm{Cu}$ (II). These are based on the ATCUN motif of the serum albumins and have been redesigned to incorporate a fluorescent reporter and to remove the response to $\mathrm{Ni}(\mathrm{II})$.

\subsection{The ATCUN Motif of the Serum Albumins}

The serum albumins are well characterized transporters of metal ions, particularly $\mathrm{Cu}(\mathrm{II})$ and $\mathrm{Ni}(\mathrm{II}){ }^{10-12} \mathrm{The}$ amino terminal $\mathrm{Cu}$ (II)- and $\mathrm{Ni}\left(\mathrm{II}\right.$ )- binding (ATCUN) motif ${ }^{13}$ of these proteins includes the consensus sequence $\mathrm{NH}_{2} \mathrm{XaaYaaHis-}$ and forms complexes having high intrinsic formation constants - on the order of $10^{11} \mathrm{M}$ for the $\mathrm{Cu}$ (II) complex. ${ }^{11}$ Coordination of $\mathrm{Cu}(\mathrm{II})$ or $\mathrm{Ni}$ (II) by the motif requires the terminal primary amine, two adjacent backbone deprotonated amide nitrogen donors, and the imidazole $\delta$-nitrogen of the histidine side chain as shown in Figure $2.13,14$

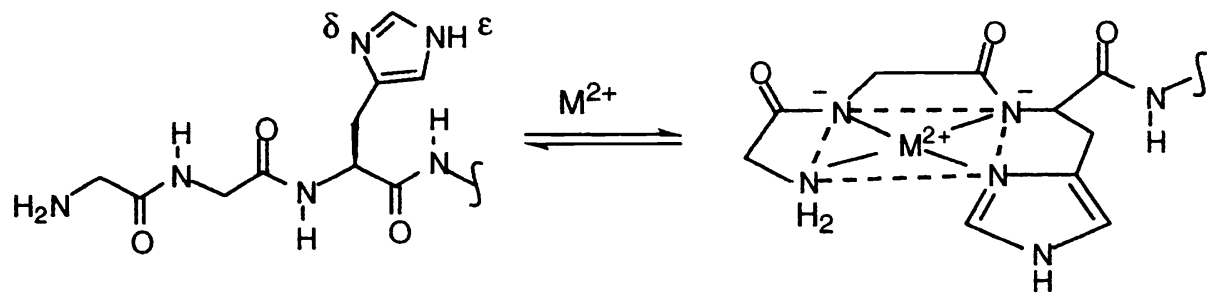

Figure 2. The serum albumin ATCUN motif.

The motif in its simplest form, the tripeptide sequence GlyGlyHis, will form stable, slightly distorted, square planar 1:1 metal:ligand complexes with both $\mathrm{Cu}(\mathrm{II})$ and $\mathrm{Ni}(\mathrm{II})$ at neutral $\mathrm{pH} .{ }^{15}$ A fluorophore can be incorporated into the structure whilst preserving the central peptidyl ligand by replacing the $N$-terminal glycine with an amino acid having a primary aminecontaining side chain and linking the fluorophore at this site during solid phase peptide synthesis. The prototypic design is illustrated in Figure 3. Peptides labeled with the dansyl (DNS) fluorophore proved highly responsive to both $\mathrm{Cu}$ (II) and $\mathrm{Ni}$ (II) under pseudo biological conditions ( $\mathrm{pH} 7.0,0.15 \mathrm{M} \mathrm{NaCl}$ ). Upon addition of either of the two metal ions, concentration dependent quenching of the fluorescence emission of DNS was observed, reaching a maximum after addition of one equivalent of the metal ion, Figure 4.16 The efficiency of quenching was dependent on both the metal ion and the length of the linker between the fluorophore and the peptidyl ligand. In all instances $\mathrm{Cu}$ (II) quenched the DNS fluorescence more efficiently than $\mathrm{Ni}$ (II), a characteristic observed in other experiments involving fluorescent (non-peptidic-) polyamide chemosensors at neutral pH. ${ }^{17}$ The efficiency of quenching increased with decreasing length of the linker between the fluorophore and the peptide backbone (Figure 4) indicating a distance dependent intramolecular mechanism for the observed quenching.

Addition of excess quantities of other divalent and trivalent metal ions such as $\mathrm{Ca}(\mathrm{II}), \mathrm{Mg}(\mathrm{II}), \mathrm{Mn}$ (II), $\mathrm{Co}$ (II), $\mathrm{Zn}$ (II), $\mathrm{Cd}(\mathrm{II}), \mathrm{Al}(\mathrm{III})$ and $\mathrm{Fe}(\mathrm{III})$ produced no significant quenching of the DNS emission. Addition of one equivalent of Fe(II) resulted in a small $(<10 \%)$ quenching effect.

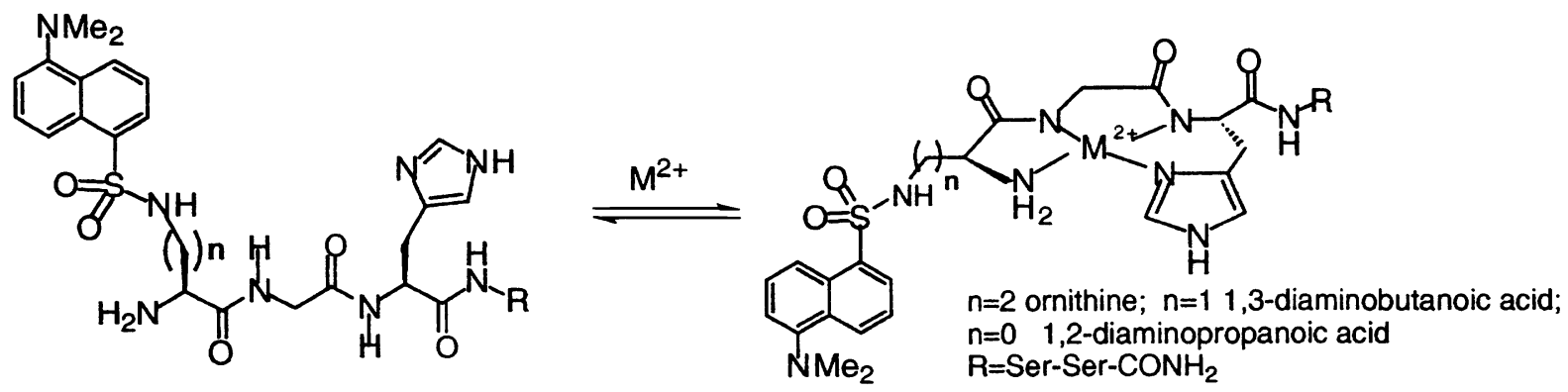

Figure 3. Incorporation of a fluorophore into the ATCUN motif results in a sensitive reporter for $\mathrm{Cu}$ (II) and $\mathrm{Ni}$ (II). 

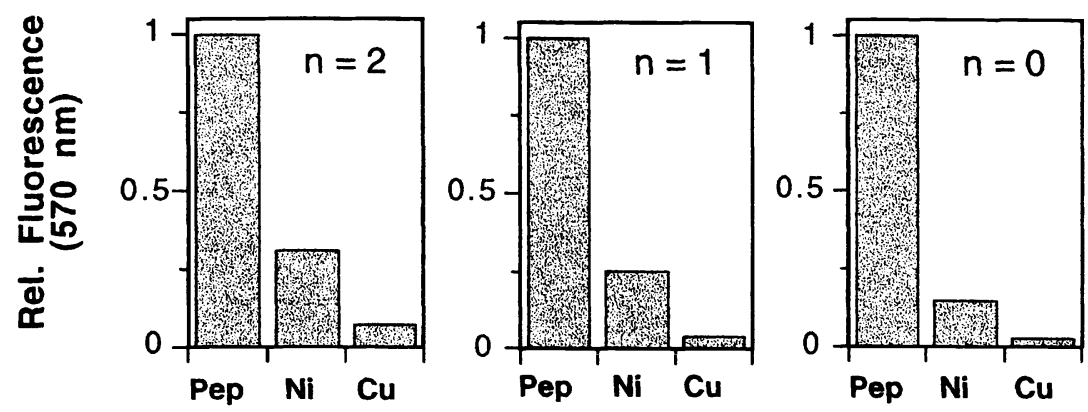

Figure 4. The chemosensor responds to $\mathrm{Cu}(\mathrm{II})$ and Ni(II) under pseudo biological conditions (pH 7.0, 0.050 M HEPES, $0.15 \mathrm{M} \mathrm{NaCl}$ ). Fluorescence quenching of the sensor is intramolecular and distance dependent. Peptide and metal ion concentrations were $10 \mu \mathrm{M}$. Excitation of the DNS was performed at $333 \mathrm{~nm}$ and fluorescence emission recorded between 450 and $650 \mathrm{~nm}$. Data have been normalized such that the fluorescence emission at $550 \mathrm{~nm}$, in the absence of metal ions, is equal to 1 .

\subsection{Generating a $\mathbf{C u}$ (II) Selective Motif}

Replacing the central glycine residue of the ATCUN motif with $\beta$-alanine introduced a six-membered chelate ring into the resulting metal complex as illustrated in Figure 5. This simple change produces a chemosensor which no longer responds to addition of $\mathrm{Ni}(\mathrm{II})$, however shows virtually no loss of sensitivity for $\mathrm{Cu}(\mathrm{II})$, Figure 6 . The change in responsiveness may be related to the more stringent requirement of low spin $\mathrm{Ni}(\mathrm{II})$ complexes for square planar geometry compared to $\mathrm{Cu}(\mathrm{II})$. Incorporation of an extra methylene group may be sufficient to distort the geometry of the resulting complex and 'detune' the response of the chemosensor towards $\mathrm{Ni}(\mathrm{II})$. $\mathrm{Cu}$ (II) is more accepting of distorted geometry on coordination and hence will still form stable complexes with the redesigned chemosensor. ${ }^{18,19}$

A number of other variants were prepared which also demonstrated new selectivities, however the $\beta$-alanine-containing peptide demonstrated optimal $\mathrm{Cu}$ (II) selectivity. The other peptide variants included different potential donors in the amino acid side chains, as well as alterations in the peptide backbone.

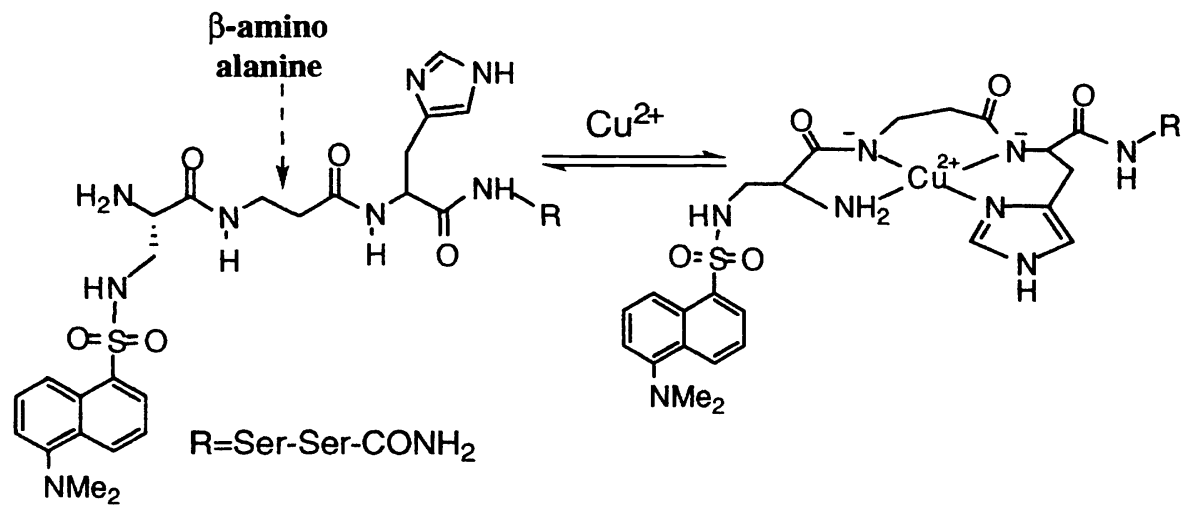

Figure 5. A simple structural change results in a $\mathrm{Cu}(\mathrm{II})$ selective response. 


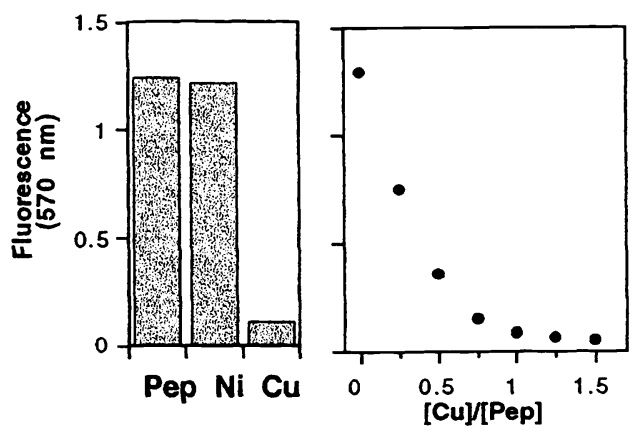

Figure 6. Fluorescence emission from the redesigned chemosensor is unresponsive to additions of excess $\mathrm{Ca}(\mathrm{II}), \mathrm{Mg}$ (II), $\mathrm{Cd}(\mathrm{II}), \mathrm{Zn}(\mathrm{II}), \mathrm{Fe}(\mathrm{II}), \mathrm{Fe}(\mathrm{III}), \mathrm{Mn}$ (II), $\mathrm{Co}(\mathrm{II}), \mathrm{Al}(\mathrm{III})$, and $\mathrm{Ni}(\mathrm{II})$, but remains very sensitive to $\mathrm{Cu}(\mathrm{II})$. Peptide and metal ion concentrations were $10 \mu \mathrm{M}$ in aqueous buffered solution ( $\mathrm{pH} 7.0,0.050 \mathrm{M}$ HEPES, $0.15 \mathrm{M} \mathrm{NaCl}$ ). Excitation of the DNS was performed at $333 \mathrm{~nm}$ and fluorescence emission recorded between 450 and $650 \mathrm{~nm}$.

\subsection{Immobilization of Peptides on Solid Supports}

The fluorescence quenching exhibited by the metal-peptide complex may be completely reversed by the addition of excess EDTA. In order to produce a chemosensor capable of being regenerated and reused, fluorophore labeled peptide sequences have been synthesized from a non-cleavable linker on PEGA-1900 resin 20,21 as shown schematically in Figure 7.

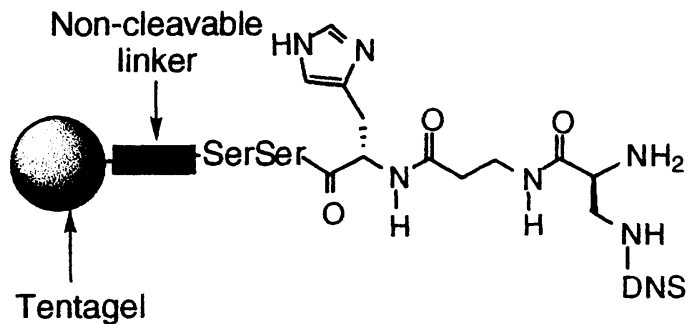

Figure 7. Synthesis of $\mathrm{Cu}$ (II)-selective chemosensor on PEGA-1900. Unlike most solid supports, this resin is capable of significant swelling in aqueous solution, allowing solution phase analytes to reach receptors in the interior of the resin beads.

Addition of metal ions to samples of such modified resins results in fluorescence quenching comparable to that exhibited in solution phase experiments. ${ }^{16}$ For example, the beads shown in Figure 8 have been modified with the $\mathrm{Cu}$ (II)-selective chemosensor described previously. Upon addition of various analytes, only $\mathrm{Cu}$ (II) quenches the DNS fluorescence emission. The quenching may be recovered by washing the beads with an EDTA solution. These experiments indicate that these chemosensors are capable of operating on solid supports and are therefore candidates for incorporation into optical sensing devices. $^{22,23}$ The studies also illustrate the potential of combinatorial methods for rapid synthesis and screening of libraries of peptides for selective responses to a wide variety of metal ion species. 


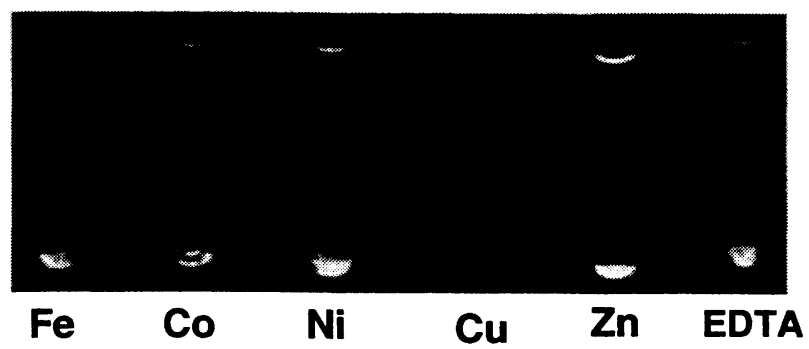

Figure 8. Quenching of $\mathrm{Cu}(\mathrm{II})$-selective chemosensor on PEGA-1900 by $\mathrm{Cu}$ (II). Small samples of beads were swollen (pH 7.0, $0.050 \mathrm{M}$ HEPES, $0.15 \mathrm{M} \mathrm{NaCl}, 10 \% \mathrm{v} / \mathrm{v}$ methanol) and treated with equal quantities of various metal ions or EDTA $(100 \mu \mathrm{M})$. Excitation of DNS was generated by a handheld low-wattage mineral lamp set on long wavelength $(365 \mathrm{~nm})$. The image was acquired following two hours incubation. Addition of methanol to the assay reduced the incubation time. Image first appeared in reference 16.

\subsection{Building a Library of Fluorescent Chemosensors}

The development of ligands for selective, sensitive recognition of target metal ions most often relies on an extensive rational design process. ${ }^{24}$ Application of the comprehensive screening methodology of combinatorial chemistry, while less well established in this particular application, represents a potentially very powerful, orthogonal strategy. 25

High throughput methods such as parallel synthesis 26 or "split and mix synthesis" generate large numbers of small molecular weight compounds that may be screened to identify a new lead compound displaying the function of interest, or to optimize an already identified lead compound. The modular constituents of combinatorial libraries need to be linked by well established chemistry and a reporter, sensitive to the function of interest, needs to be incorporated on each bead or within each molecule of the library.

The peptidyl chemosensors described in this paper are modular constructs and therefore are amenable to combinatorial synthesis methods. To examine the potential of such techniques to our own research program, a small library of pentapeptide sequences having the general form XaaYaaZaaSerSer-PEGA-1900 (Xaa = Gly, His, Pro, $\beta$-Ala; Yaa $=$ Gly, His, $\beta$-Ala; Zaa $=$ Gly, His, $\beta$-Ala; Ser = serine) was prepared. The sequences were chosen to vary the size and sequence of the resulting chelate rings, the presence/absence of the imidazole side chain of histidine, and a primary or secondary (proline) amine at the $N$ terminus of the peptide. Figure 9 illustrated the results from a typical experiment in which $\mathrm{Cu}$ (II) has been added to a sample of the library. Allowing for bead size distribution (and associated kinetics of analyte diffusion), differences in fluorescence quenching of individual beads is apparent. After a two hour incubation the fluorescence of many beads is significantly reduced, while other beads are still highly fluorescent. The fluorescence of individual beads may also rerecorded. As shown in Figure 9B it is possible to generate a quantitative assessment of an individual sequence response to added analyte by monitoring the kinetic course of fluorescence quenching. The library, although relatively small, still contains sequences that bind $\mathrm{Cu}(\mathrm{II})$ with a range of affinities. Beads modified by sequences that bind $\mathrm{Cu}(\mathrm{II})$ strongly, are quenched completely and rapidly, while those with poor affinity for the metal ion remain fluorescent for the duration of the experiment. These studies indicate that applying combinatorial methods in our search for metal ion chemosensors will prove fruitful. 
A

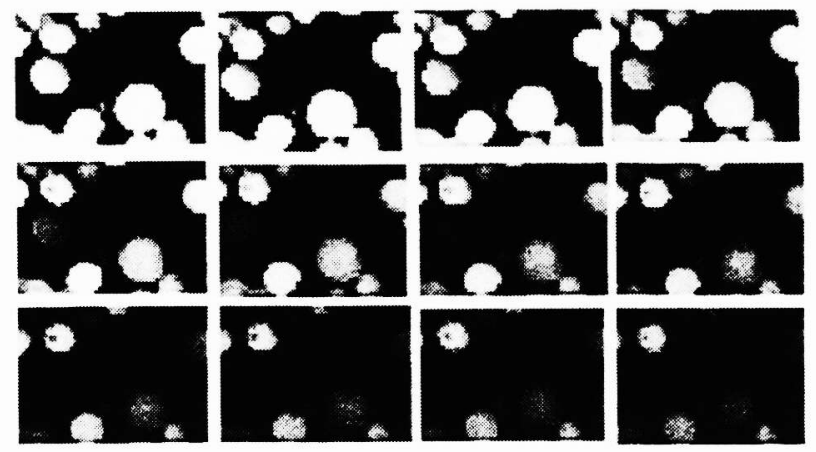

B

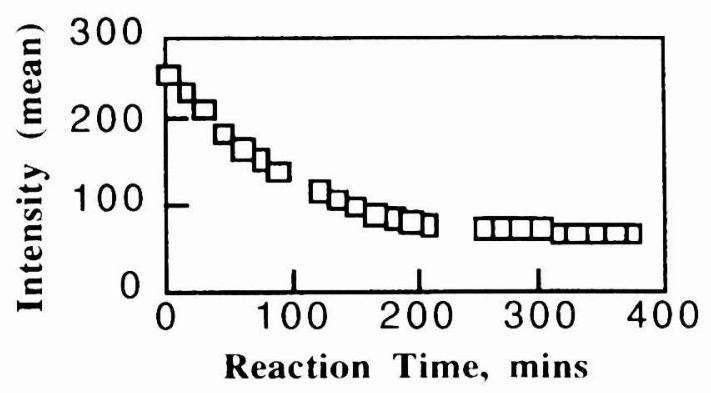

Figure 9. Addition of $\mathrm{Cu}(\mathrm{II})$ to chemosensors of the general sequence XaaYaaZaaSerSer-PEGA-1900. The fluorescence, due to the incorporation of the DNS fluorophore into the sequences, is quenched on addition of $\mathrm{Cu}(\mathrm{II})$ to the library. Samples of the library were swollen $(\mathrm{pH} 7.0,0.050 \mathrm{M}$ HEPES, $0.15 \mathrm{M} \mathrm{NaCl}, 10 \% \mathrm{v} / \mathrm{v}$ methanol) and treated with excess Cu(II) ( 100 $\mu \mathrm{M}$ ). A. Images were recorded (from top right to bottom left) at $0,15,30,60,90,120,150,180,210,255,300$ and 360 min respectively. B. Analysis of images allows quantitative measurement of on-bead fluorescence of single beads.

\section{DES IGN O F S ELEC TIVE C HEMOS ENSO RS FO R FE(III)}

The chemosensors which selectively recognize $\mathrm{Cu}$ (II) were based on the $\mathrm{N}$-terminal consensus sequence found in the serum albumins and prepared using naturally occurring amino acids as ligands. In designing chemosensors for $\mathrm{Fe}(\mathrm{III})$, the design has again been based on motifs present in biological systems. However, in this case the modular nature of solid phase peptide synthesis has been used to incorporate non-natural ligating amino acids into the sensor sequences.

\subsection{Siderophores - Bacterial Fe(III) Transport Vehicles}

Siderophores are low molecular weight chelating agents produced by bacteria that bind $\mathrm{Fe}$ (III) avidly (forming complexes with formal stability constants in the range $\left.10^{30}-10^{49}\right){ }^{28}$ Structures of two of the best characterized siderophores, enterobactin and desferrioxamine B, are shown in Figure 10. Enterobactin coordinates Fe(III) through the pendent catechol moieties whereas desferrioxamine B forms the $\mathrm{Fe}$ (III) complex with hydroxamatc and carbonyl donors. A recent publication describes a fluorescent chemosensor formed by the simple, but effective, process of capping the $N$-terminus of this bacterial product with a fluorophore such as anthracene. ${ }^{29}$ Our design process involves taking the catechol unit from enterobactin and preparing novel amino acids including this unit in an amino acid side chain. The resulting residues have been incorporated into peptides via standard solid phase peptide synthesis methods to generate species having quite different structures and sensitivities to the presence of $\mathrm{Fe}(\mathrm{III})$ in aqueous solution.<smiles>O=COCC(NC(=O)c1cccc(O)c1O)C(=O)OCCNC(=O)c1cccc(O)c1O</smiles>

B<smiles>[X][Y](=O)N(O)C(=O)CCC(=O)NNC(=O)CCC(=O)N(O)O</smiles>

$$
X=\left(\mathrm{CH}_{2}\right)_{5}
$$

Figure 10. Siderophores involved in coordination and transport of $\mathrm{Fe}(\mathrm{III})$ in bacterial systems. A. Enterobactin; B.

\section{Desferroxamine.}




\subsection{Design of Fuorescent Catecholate Peptides for Sensing Fe(III)}

The catechol unit is attached to the central macrocycle of enterobactin by an amide link; this linkage provides a route by which the unit may be incorporated into a peptide sequence in a combinatorial manner. A family of novel amino acids has been prepared such that the protected catechol unit was tethered to the amine of an $N-\alpha$-Fmoc-protected amino acid by a linker between one and four methylene units in length. The resulting amino acids have been incorporated into peptides using standard Fmoc-based solid phase synthesis. ${ }^{30}$ The peptide shown in Figure 12, is a typical example of the peptides prepared in this manner. Three catechol amino acids are introduced into a sequence that has been shown to form a $\beta$-hairpin turn in aqueous solution. ${ }^{31}$ The $N$-terminal amine of the peptide is capped by the fluorophore diethylaminocoumarin (DE) to provide a reporter of metal ion binding and to prevent the $N$-terminal amine and adjacent amide nitrogens from providing a binding site for species such as $\mathrm{Cu}$ (II). This peptide binds $\mathrm{Fe}$ (III) avidly, being capable of competing with the synthetic analog TRENCAM ${ }^{32}$ for available Fe(III). Besides Fe(III), only $\mathrm{Cu}$ (II) and Fe(II) have been shown to produce significant quenching of fluorescence from this chemosensor.<smiles>O=C(O)c1cccc(O)c1O</smiles><smiles>COC(=O)c1cccc(OC)c1OC</smiles><smiles>COc1cccc(C(=O)[O-])c1OC</smiles><smiles>COc1cccc(C(=O)NN=C(NC(=O)OCC2c3ccccc3-c3ccccc32)C(=O)O)c1OC</smiles>

Figure 11. Synthesis of catechol containing amino acids for synthesis of Fe(III) chemosensors.

The chemosensor molecules are capable of functioning in complex biological mixtures; the chemosensor is fluorescent in serum and sensitive to addition of target analyte. Addition of aliquots of Fe(III) to a solution of the chemosensor in fetal bovine serum (FBS) are clearly distinguishable and indicated by the progressive quenching of the fluorescence emission, Figure 12.

A<smiles>CC[C@H](NC(=O)[C@H](CO)NC(=O)C1CCCN1C(=O)C(CCCNC(=O)c1cccc(O)c1O)NC(=O)CN(CCNC(=O)c1cccc(O)c1O)C(=O)CNC(=O)c1cc2ccc(N(CC)CC)cc2oc1=O)C(=O)N[C@@H](CO)C(=O)N[C@@H](CO)C(N)=O</smiles>

B

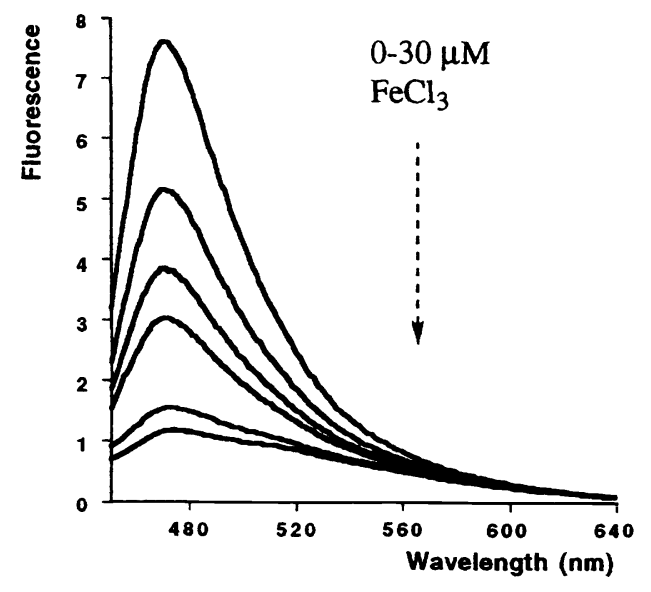

Figure 12. Addition of $\mathrm{Fe}(\mathrm{III})(1.1-5.5 \mu \mathrm{M})$ to a solution of $\mathrm{Fe}(\mathrm{III})$-selective chemosenor peptide $(5.5 \mu \mathrm{M})$ in dialyzed FBS. 


\section{CONCLUSION}

Many examples of biological motifs that bind certain transition metal ions with high affinity in the presence of other metal ions at much higher concentrations can be found in the literature. These motifs may be used as lead compounds in the preparation of metal ion recognition units in fluorescent chemosensors for $\mathrm{Cu}$ (II) or $\mathrm{Fe}$ (III). The modular nature of peptides makes these chemosensors well suited to the techniques of combinatorial chemistry. Parallel synthesis can be used to introduce subtle modifications into the chemosensor design and the ability of the resulting families of sensors may be assayed either in solution or while still attached to the solid support on which they were prepared.

\section{REFERENCES}

1. S. J. Lippard, and J. M. Berg, Principles of Bioinorganic Chemistry, University Science Books, Mill Valley California, 1994.

2. M. D. Harrison, C. E. Jones, and C. T. Dameron, "Copper chaperones: function, structure and copper-binding properties," J. Biol. Inorg. Chem., 4, pp. 145-153, 1999.

3. A. L. Crumbliss, "Iron Bioavailability and the Coordination Chemistry of Hydroxamic Acids," Coord. Chem. Rev., 105, pp. 155-179, 1990.

4. H. Siegel, Metal Ions in Biological Systems: Concepts on Metal Ions Toxicity, Marcel Decker Inc., New York, 1986.

5. M. C. Linder, and C. A. Goode, Biochemistry of Copper, Plenum Press, New York, 1991.

6. M. J. Beherenfeld, A. J. Bale, Z. S. Kolber, J. Aiden, and P. G. Falkowski, "Confirmation of iron limitation of phytoplankton photosynthesis in the equatorial Pacific Ocean," Nature, 383, pp. 508-511, 1996.

7. A. P. deSilva, H. Q. N. Gunaratne, T. Gunnlaugsson, A. J. M. Huxley, C. P. McCoy, J. T. Rademacher, and T. E. Rice, "Signaling recognition events with fluorescent sensors and switches," Chem. Rev., 97, pp. 1515-1566, 1997.

8. K. L. Michael, L. C. Taylor, S. L. Shultz, and D. R. Walt, "Randomly ordered addressable high-density optical sensor arrays," Anal. Chem., 70, pp. 1242-1248, 1998.

9. R. Tsien, "Fluorescence imaging creates a window on the cell," C\&E News, 72, pp. 34-44, 1994.

10. J. Masuoka, and P. Saltman, "Zinc(II) and copper(II) binding to serum-albumin - a comparative-study of dog, bovine, and human albumin," J. Biol. Chem., 269, pp. 25557-25561, 1994.

11. J. Masuoka, J. Hegenauer, B. R. Vandyke, and P. Saltman, "Intrinsic stoichiometric equilibrium-constants for the binding of zinc(II) and copper(II) to the high-affinity site of serum-albumin," J. Biol. Chem., 268, pp. 21533-21537, 1993.

12. P. F. Predki, C. Harford, P. Brar, and B. Sarkar, "Further characterization of the N-terminal copper(II) binding and nickel(II) binding motif of proteins - studies of metal-binding to chicken serum-albumin and the native sequence peptide," Biochem. J., 287, pp. 211-215, 1992.

13. C. Harford, and B. Sarkar, "Amino terminal Cu(II)- and Ni(II)-binding (ATCUN) motif of proteins and peptides: metal binding, DNA cleavage and other properties," Acc. Chem. Res., 30, pp. 123-130, 1997.

14. T. P. A. Kruck, S. Lau, and B. Sarkar, "Molecular design to mimic the copper(II) transport site of human albumin: studies of equilibria between copper(II) and glycylglycyl-L-histidine- $N$-methyl amide and comparison with human albumin," Can. J. Chem., 54, pp. 1300-1308, 1976.

15. K. A. Koch, M. M. O. Peña, and D. J. Thiele, "Copper binding motifs in catalysis, transport, detoxifiction and signaling," Chem. Biol., 4, pp. 549-560, 1997.

16. A. Torrado, G. K. Walkup, and B. Imperiali, "Exploiting polypeptide motifs for the design of selective $\mathrm{Cu}(\mathrm{II}) \mathrm{ion}$ chemosensors," J. Am. Chem. Soc., 120, pp. 609-610, 1998.

17. L. Fabbrizzi, L. Licchelli, and D. Sacchi, "An anthracene-based fluorescent sensor for transition-metal ions," Angew. Chem. Int. Edit., 33, pp. 1975-1977, 1994.

18. H. Sigel, and R. B. Martin, "Coordinating properties of the amide bond. Stability and structure of metal ion complexes of peptides and related ligands," Chem. Rev., 82, pp. 385-426, 1982.

19. H. Sigel, B. Prijs, and R. B. Martin, "Stability of binary and ternary $\beta$-alanine containing dipeptide copper(II) complexes," Inorg. Chim. Acta, 56, pp. 45-49, 1981.

20. M. Meldal, F. I. Auzanneau, O. Hindsgaul, and M. M. Palcic, "A PEGA resin for use in the solid-phase chemicalenzymatic synthesis of glycopeptides," J. Chem. Soc. Chem. Commun., 16, pp. 1849-1850, 1994.

21. M. Meldal, "PEGA - a flow stable polyethylene-glycol dimethyl acrylamide copolymer for solid-phase synthesis," Tetrahedron Lett., 33, pp. 3077-3080, 1992.

22. D. R. Walt, "Fiber optic imaging sensors," Acc. Chem. Res., 31, pp. 267-278, 1998. 
23. J. J. Lavigne, S. Savoy, M. B. Clevenger, J. E. Ritchie, B. McDoniel, S. J. Yoo, E. V. Anslyn, J. T. McDevitt, J. B. Shear, and D. Neikirk, "Solution-based analysis of multiple analytes by a sensor array: toward the development of an "electronic tongue"," J. Am. Chem. Soc., 120, pp. 6429-6430, 1998.

24. L. F. Lindoy, "Tailoring macrocycles for metal ion binding," Pure Appl. Chem., 69, pp. 2179-2186, 1997.

25. A. W. Czarnik, "Combinatorial Chemistry - What's in it for analytical chemists?," Anal. Chem., 70, pp. 378A-386A, 1998.

26. M. C. Pirrung, "Spatially addrssable combinatorial libraries," Chem. Rev., 97, pp. 473-488, 1997.

27. K. S. Lam, M. Lebl, and V. Krchnak, "The "one-bead-one-compound" combinatorial library method," Chem. Rev., 97, pp. 411-448, 1997.

28. Z. Hou, T. D. P. Stach, C. J. Sunderland, and K. N. Raymond, "Enhanced iron(III) chelation through ligand predisposition: syntheses, structures and stability of tris-catecholate enterobactin analogs," Inorg. Chim. Acta and references therein, 263, pp. 341-355, 1997.

29. T. Palanche, F. Marmolle, M. A. Abdallah, A. Shanzer, and A. M. Albrecht-Gary, "Fluorescent siderophore-based chemosensors: iron(III) quantitative determinations," J. Biol. Inorg. Chem., 4, pp. 188-198, 1999.

30. M. Bodanszky, Peptide Chemistry: A Practical Textbook, Springer-Verlag, Berlin, 1993.

31. S. J. Rogers, C. W. Lee, C. Y. Ng, and K. N. Raymond, "Ferric ion sequestering agents. 15. Synthesis, solution chemistry, and electrochemistry of a new cationic analog of enterobactin," Inorg. Chem., 26, pp. 1622-1625, 1987. 